\title{
Evaluation of Percutaneous and Surgical Tracheostomy Results in Neurocritical Care Unit
}

\author{
Nöroyoğun Bakımda Perkütan ve Cerrahi Trakeostomi Sonuçlarının \\ Değerlendirilmesi
}

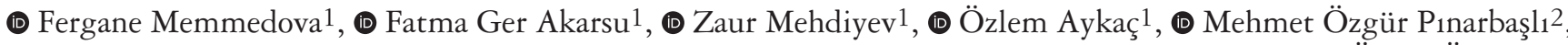
(1) Melek Kezban Gürbüz ${ }^{2}$, (1) Atilla Özcan Özdemir ${ }^{1}$

\author{
${ }^{1}$ Eskisehir Osmangazi University Faculty of Medicine Hospital, Department of Neurology, Eskisehir, Turkey \\ 2Eskisehir Osmangazi University Faculty of Medicine Hospital, Department of Otorhinolaryngology, Eskisehir, Turkey
}

\begin{abstract}
Objective: The aim of the study is to evaluate the advantages and disadvantages,complication and mortality rates of percutaneous and surgical tracheostomy procedures performed in patients in neuro-intensive care unit (neuro-ICU).

Materials and Methods: The study was carried out retrospectively in neuro-ICU. Patients' demographic characteristics, comorbidities, reasons for hospitalization, ICU scores at admission [Acute Physiology and Chronic Health Evluation 2 (APACHE 2) score and Sequential Organ Failure Assessment (SOFA) score], intubation period (days), length of stay in ICU, procedural complications, mortality rates, modified Rankin scale (mRS) scores at discharge and $3^{\text {rd }}$ month were evaluated. Surgical and percutaneous tracheostomy results were compared. Laryngeal mask airway (LMA), bronchoscopy, and tube withdrawal procedures used in percutaneous tracheostomy were compared as well.

Results: Fifty five patients were included in the study. Of the patients, $60.0 \%$ were male. Mean age was $71.4 \pm 11.8$ years. The APACHE 2 score was $25.4 \pm 4.8$ and SOFA score was $8.1 \pm 2.7$ at admission to ICU. Mean number of intubation days of the patients was $20.7 \pm 11.8$, and mean length of stay in ICU was $33.1 \pm 13.0$ days. Tracheostomy procedure was successful in $53(96.4 \%)$ patients, complications were encountered in $5(9.1 \%)$ patients among all (succesful and unsuccessful) intervention groups. Mortality was seen in 23 (41.8\%) patients. Three-month mRS was 5 in 32 (\%58.2) patients. Duration of stay in ICU, intubation period (days), and time between intensive care hospitalization and tracheostomy (days) in surgery group were significantly longer compared to percutaneous tracheostomy group. No statistically significant difference was observed in comparison of different groups such as LMA, tube withdrawal, bronchoscopy in patients undergoing percutaneous tracheostomy.

Conclusion: In the study in which we compared the surgical and percutaneous tracheostomy results, no statistically significant difference was found in the complication rates and $\mathrm{mRS}$ score at discharge of the two groups. In-hospital mortality rate, which was defined as mRS 6, was observed to be higher in patients who underwent surgical tracheostomy. Because of the rapid application of the procedure at the bedside in patients for whom percutaneous tracheostomy was preferred, it was observed that the length of stay in the neuro-ICU and the number of days followed up with intubation were reduced.
\end{abstract}

Keywords: Neurological intensive care unit, percutaneous tracheostomy, surgical tracheostomy

\section{$\ddot{O} \mathbf{z}$}

Amaç: Çalışmanın amacı, nöroloji yoğun bakım ünitesi (YBÜ) hastalarında uygulanan perkütan ve cerrahi trakeostomi işlemlerinin avantaj ve dezavantajları, komplikasyon ve ölüm oranlarını değerlendirmektir.

Gereç ve Yöntem: Çalışma 3. basamak nöroloji YBÜ’de retrospektif olarak gerçekleştirildi. Hastaların demografik özellikleri, komorbiditeleri, yatış nedenleri, YBÜ’ye giriş skorları [Akut Fizyoloji ve Kronik Sağlık Değerlendirmesi 2 skoru (APACHE 2) ve Ardışık Organ Yetmezliği Değerlendirme skoru (SOFA)], entübasyon süreleri (gün), yoğun bakımda kalış süresi, işlem komplikasyonu ve mortalite oranları, taburculuk durumu ve 3. ay modifiye Rankin skalası (mRS) skorları değerlendirildi. Cerrahi ve perkütan trakeostomi sonuçları karşılaştıııldı. Aynı zamanda perkütan trakeostomide kullanılan laringeal maske (LMA), bronkoskopi ve tüpü geri çekme yöntemleri karşılaştırıldı.

Bulgular: Çalışmaya 55 hasta dahil edildi. Hastaların 33’ü $(\% 60,0)$ erkekti. Yaş ortalaması $71,4 \pm 11,8$ yıldı. Komorbidite olarak hipertansiyon 35 (\%63,6) hastada, diabetes mellitus $19(\% 34,5)$ hastada ve inme $10(\% 18,2)$ hastada mevcuttu. Yatı̧ tanıları olarak; iskemik inme $37(\% 67,3)$ hastada, hemorajik inme 7 $(\% 12,7)$ hastada, amiyotrofik lateral skleroz $5(\% 9,1)$ hastada, koronavirüs hastalığ $($ COVID-19 pnömonisi) $2(\% 3,6)$ hastada, miyastenia gravis $1(\% 1,8)$ hastada,

Address for Correspondence/Yazışma Adresi: Fergane Memmedova MD, Eskisehir Osmangazi University Faculty of Medicine Hospital, Department of Neurology, Eskisehir, Turkey Phone: +90 5346799629 E-mail: drfergane@gmail.comORCID: orcid.org/0000-0003-3021-1688

Received/Gelis Tarihi: 28.09.2021 Accepted/Kabul Tarihi: 17.01 .2022

${ }^{\circ}$ Copyright 2022 by Turkish Neurological Society

Turkish Journal of Neurology published by Galenos Publishing House. 


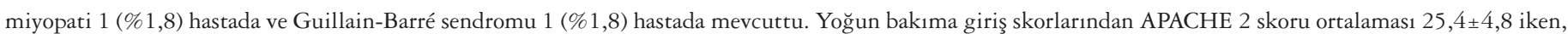

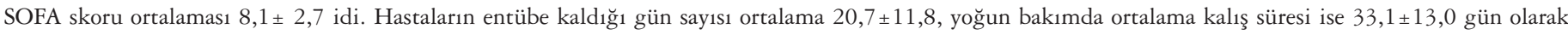

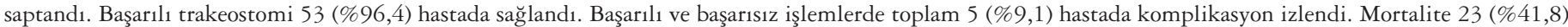

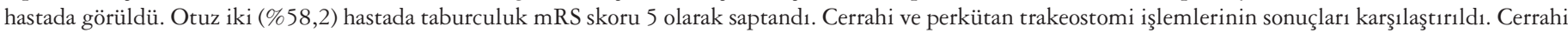

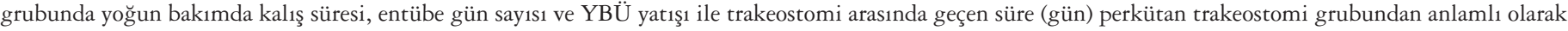

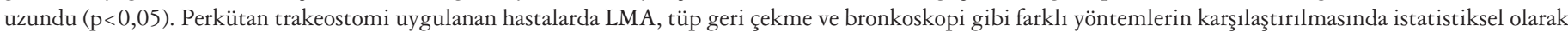
anlamli farklılık izlenmedi.

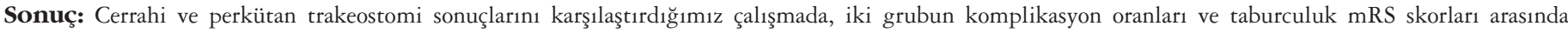

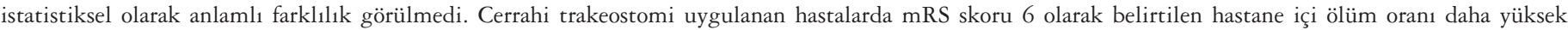

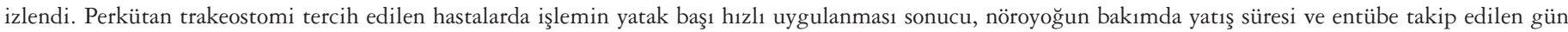
sayısının azaldı̆̆ 1 görüldü.

Anahtar Kelimeler: Nöroloji yoğun bakım, perkütan trakeostomi, cerrahi trakeostomi

\section{Introduction}

Patients with stroke constitute the majority of patients in neurology intensive care units (ICU). Herniation may develop due to extensive cerebral damage and respiratory and cardiac functions may be adversely affected due to brain stem compression. These patients are intubated and followed up with a ventilator, and extubation attempts may fail during intensive care follow-up. Tracheostomy is recommended in neurointensive care patients whose intubated follow-up days are prolonged up to 2-3 weeks and extubation attempts are unsuccessful. Early tracheostomy placement reduces the need for prolonged mechanical ventilation and the length of stay in the ICU. It also reduces the rate of pneumonia and the need for analgesic and sedative drugs. It facilitates oropharyngeal hygiene, swallowing evaluation, aspiration and nursing care procedures, and increases patient comfort $(1,2,3,4)$.

Tracheostomy can be performed in two ways as surgical and percutaneous (3). Percutaneous tracheostomy may be preferred as an alternative to surgical tracheostomy, especially for patients in the ICU (5). In our study, we aimed to evaluate the advantages/ disadvantages, complication rates, modified Rankin scale (mRS) scores at discharge and $3^{\text {rd }}$ month of percutaneous and surgical tracheostomy procedures in patients treated and followed up in a tertiary neurology ICU.

\section{Materials and Methods}

The study was carried out in Eskisehir Osmangazi University Faculty of Medicine, Neurology ICU. After the study was approved by the Eskisehir Osmangazi University Faculty of Medicine Ethics Committee (decision number: E-25403353-050.99-183151), the data of all patients who were hospitalized in the tertiary neuro-ICU and underwent tracheostomy between 01.01.2020 and 31.06.2021 were retrospectively analyzed. Demographic characteristics of patients, comorbidities, reasons for hospitalization [such as ischemic stroke, hemorrhagic stroke, amyotrophic lateral sclerosis, myasthenia gravis, myopathy, Guillain-Barré syndrome (GBS)], Acute Physiology and Chronic Health Evluation 2 (APACHE 2) score, Sequential Organ Failure Assessment (SOFA) score, Charlson comorbidity index, number of days intubated, length of stay in the tertiary ICU, mRS scores at discharge and $3^{\text {rd }}$ month were evaluated. Surgical tracheostomy and bedside percutaneous tracheostomy results were compared in terms of mortality, complication rates, and length of stay in the ICU. At the same time, the results of technical methods such as the use of laryngeal mask airway (LMA), tube withdrawal and bronchoscopy in patients who underwent percutaneous tracheostomy were compared, and the differences in procedural success rates, complication rates, and length of stay in the ICU were evaluated.

\section{Tracheostomy Technique}

Surgical tracheostomy was performed under general anesthesia in operating room conditions by otolaryngologists in some of the patients who underwent tracheostomy. Anatomical characteristics of the patients (short neck, scoliosis), obesity, and thyroiditis were taken into account for surgical tracheostomy indication.

In most of the patients, bedside percutaneous tracheostomy was performed in the ICU. Three different techniques were used in percutaneous tracheostomy procedures: Bronchoscopy, LMA and endotracheal tube withdrawal. In this group, appropriate doses of intravenous anesthetics (midazolam, propofol, fentanyl) and muscle relaxants (esmeron) were used for sedation purposes. After the neck area of the patients who underwent percutaneous tracheostomy was wiped with antiseptic solution and covered with a sterile drape, subcutaneous local anesthetic agent was applied. Then, the balloon of the endotracheal tube was deflated and withdrawn so that its distal end was just below the vocal cords. In patients in whom LMA was used, the tube was withdrawn with aspiration and replaced with LMA. After palpating the second and third intervals of the tracheal cartilage, the $14 \mathrm{G}$ needle was advanced vertically into the tracheal lumen. Then, after the guide wire was placed in the tracheal lumen, the needle was withdrawn and the incision area was widened with a dilator. The skin, subcutaneous tissue and trachea were expanded with forceps. The appropriate size tracheostomy tube was placed in the trachea. The endotracheal tube/LMA was removed after the balloon of the tracheostomy cannula was inflated and the location of the cannula was confirmed by listening for respiratory sounds.

\section{Statistical Analysis}

Mean, standard deviation, median (minimum-maximum), frequency and ratio values were used in the descriptive statistics of the data. The distribution of variables was measured with the Kolmogorov-Smirnov test. The Kruskal-Wallis and MannWhitney $U$ tests were used in the analysis of quantitative independent data. Chi-square test was used in the analysis of qualitative independent data, and the Fischer Exact test was used when the chi-square test conditions were not met. Analyzes were performed with the SPSS 27.0 program. 


\section{Results}

Tracheostomy was performed in $55(28.64 \%)$ of 192 patients hospitalized in the neurology ICU during the study period. Of the patients, $33(60.0 \%)$ were male and $22(40.0 \%)$ were female. The mean age was $71.4 \pm 11.8$ years. Hypertension was present in $35(63.6 \%)$, diabetes mellitus in $19(34.5 \%)$ and previous stroke in $10(18.2 \%)$ patients. In patients who underwent tracheostomy, the reason for hospitalization were ischemic stroke in $37(67.3 \%)$ patients, hemorrhagic stroke in $7(12.7 \%)$ patients, amyotrophic lateral sclerosis in $5(9.1 \%)$ patients, coronavirus disease (COVID-19) pneumonia in $2(3.6 \%)$ patients, myasthenia gravis in $1(1.8 \%)$ patient, myopathy in $1(1.8 \%)$ patient, and GBS in 1 $(1.8 \%)$ patient. While the APACHE 2 mean at admission to the ICU was $25.4 \pm 4.8$, the mean SOFA score was $8.1 \pm 2.7$. Charlson comorbidity index was $7.2 \pm 2.4$. The mean number of days the patients were intubated was $20.7 \pm 11.8$ days, and the mean length of stay in the ICU was $33.1 \pm 13.0$ days. Tracheostomy was performed on an average of $24.8 \pm 13.2$ days of ICU hospitalization. Tracheostomy was successfully performed in $53(96.4 \%)$ patients. In 3 patients who had a successful procedure, bleeding in the form of leakage around the tracheostomy was observed in the post-procedure period. The reason for this was that tracheostomy procedure was performed in patients with newly inserted stent without discontinuing antiaggregant treatment. One of these patients underwent surgical procedure, and the other two patients underwent percutaneous tracheostomy. Complications were encountered in a total of $5(9.1 \%)$ patients, including 3 patients who continued to bleed in the form of leakage for a few days despite the successful procedure and spontaneously recovered, and 2 patients who had an unsuccessful procedure as a result of incorrect passage and died within 24 hours. Apart from this, no death was observed as a result of the tracheostomy procedure. No complications related to the anesthetic agents used were observed. The number of patients with mRS 6 at discharge was 23 (41.8\%). The major causes of mortality in these patients were sepsis and multiple organ failure. The number of patients with a discharge mRS of 5 was $32(58.2 \%)$. When the $3^{\text {rd }}$ month mRS of these patients was examined, it was seen that 12 of 32 patients resulted in death within 3 months. The mRS score of 17 (30.9\%) patients was 5, $2(3.6 \%)$ patients had an mRS score of 4 , and $1(1.8 \%)$ patient who was admitted to the neuro-ICU with the diagnosis of COVID-19 pneumonia and had no cerebrovascular disease had an mRS score of 1 (Table 1). Surgery was performed in 15 $(27.3 \%)$ patients, and percutaneous tracheostomy was performed in $40(72.7 \%)$ patients. Comparison results of surgical and percutaneous tracheostomy procedures are given in Table 2. The length of stay in the ICU was significantly longer in patients who underwent surgery than in patients who underwent percutaneous tracheostomy $(\mathrm{p}=0.035)$, and the number of days intubated was longer in patients who underwent surgery than in patients who underwent percutaneous tracheostomy $(\mathrm{p}=0.004)$. Tracheostomy time in the ICU was longer in the surgical procedure group than in the percutaneous tracheostomy group $(\mathrm{p}=0.032)$. There was no significant difference between the procedural success, complication rates, discharge and $3^{\text {rd }}$ month mRS score of the two groups. While no procedure failure was observed in the surgical procedure group, it was seen in $2(5.0 \%)$ patients in the percutaneous tracheostomy group. There was no statistically significant difference between
Table 1. Characteristics of the patients

\begin{tabular}{|c|c|c|c|}
\hline & $\begin{array}{l}\text { Minimum- } \\
\text { maximum }\end{array}$ & Median & $\begin{array}{l}\text { Mean } \pm \\
\text { SD/n }(\%)\end{array}$ \\
\hline Age & $48-93.0$ & 73,0 & $71.4 \pm 11.8$ \\
\hline \multicolumn{4}{|l|}{ Gender } \\
\hline Female & - & - & $22(40.0 \%)$ \\
\hline Male & - & - & $33(60.0 \%)$ \\
\hline \multicolumn{4}{|l|}{ Comorbidity } \\
\hline Hypertension & - & - & $35(63.6 \%)$ \\
\hline Diabetes mellitus & - & - & $19(34.5 \%)$ \\
\hline Ischemic stroke & - & - & $10(18.2 \%)$ \\
\hline \multicolumn{4}{|l|}{ Diagnosis } \\
\hline Ischemic stroke & - & - & $37(67.3 \%)$ \\
\hline Hemorrhagic stroke & - & - & $7(12.7 \%)$ \\
\hline $\begin{array}{l}\text { Amyotrophic lateral } \\
\text { sclerosis }\end{array}$ & - & - & $5(9.1 \%)$ \\
\hline Myasthenia gravis & - & - & $1(1.8 \%)$ \\
\hline Myopathy & - & - & $1(1.8 \%)$ \\
\hline Guillain-Barré syndrome & - & - & $1(1.8 \%)$ \\
\hline $\begin{array}{l}\text { Hydrocephalus + status } \\
\text { epilepticus }\end{array}$ & - & - & $1(1.8 \%)$ \\
\hline COVID-19 pneumonia & - & - & $2(3.6 \%)$ \\
\hline APACHE 2 score & $15.0-35.0$ & 25.0 & $25.4 \pm 4.8$ \\
\hline SOFA score & $3.0-17.0$ & 8.0 & $8.1 \pm 2.7$ \\
\hline Charlson comorbidity index & $3.0-13.0$ & 7.0 & $7.2 \pm 2.4$ \\
\hline $\begin{array}{l}\text { Length of stay in intensive } \\
\text { care unit (days) }\end{array}$ & $4.0-60.0$ & 35.0 & $33.1 \pm 13.0$ \\
\hline Intubation (days) & $2.0-41.0$ & 22.0 & $20.7 \pm 11.8$ \\
\hline $\begin{array}{l}\text { Time between intensive } \\
\text { care admission and } \\
\text { tracheostomy (days) }\end{array}$ & $2.0-49.0$ & 26.0 & $24.8 \pm 13.2$ \\
\hline \multicolumn{4}{|l|}{ Anesthesia during the procedure } \\
\hline General anesthesia & - & - & $15(27.3 \%)$ \\
\hline Neurosedation & - & - & $40(72.7 \%)$ \\
\hline \multicolumn{4}{|l|}{ Neurosedative agents } \\
\hline Midazolam & - & - & $37(67.3 \%)$ \\
\hline Propofol & - & - & $5(9.1 \%)$ \\
\hline Fentanyl & - & - & $36(65.5 \%)$ \\
\hline Esmeron & - & - & $38(69.1 \%)$ \\
\hline \multicolumn{4}{|l|}{ Successful procedure } \\
\hline Yes & - & - & $53(96.4 \%)$ \\
\hline No & - & - & $2(3.6 \%)$ \\
\hline Use of laryngeal mask & - & - & $17(42.5 \%)$ \\
\hline Tube withdrawal & - & - & $12(30.0 \%)$ \\
\hline Use of bronchoscopy & - & - & $11(27.5 \%)$ \\
\hline \multicolumn{4}{|l|}{ Complication } \\
\hline$(-)$ & - & - & $50(90.9 \%)$ \\
\hline$(+)$ & - & - & $5(9.1 \%)$ \\
\hline \multicolumn{4}{|l|}{$\mathrm{mRS}$ at discharge } \\
\hline$-\operatorname{mRS} 5$ & - & - & $32(58.2 \%)$ \\
\hline$-\operatorname{mRS} 6$ & - & - & $23(41.8 \%)$ \\
\hline \multicolumn{4}{|l|}{$\mathrm{mRS}$ at 3 months } \\
\hline- mRS 3 & - & - & $1(1.8 \%)$ \\
\hline - mRS 4 & - & - & $2(3.6 \%)$ \\
\hline$-\operatorname{mRS} 5$ & - & - & $17(30.9 \%)$ \\
\hline - mRS 6 & - & - & $35(63.6 \%)$ \\
\hline
\end{tabular}

SD: Standard deviation, COVID-19: Coronavirus disease-2019, APACHE 2: Acute Physiology and Chronic Health Evluation 2 score, Sequential Organ Failure Assessment score, mRS: Modified Rankin scale 
Table 2. Evaluation of surgical and percutaneous tracheostomy results

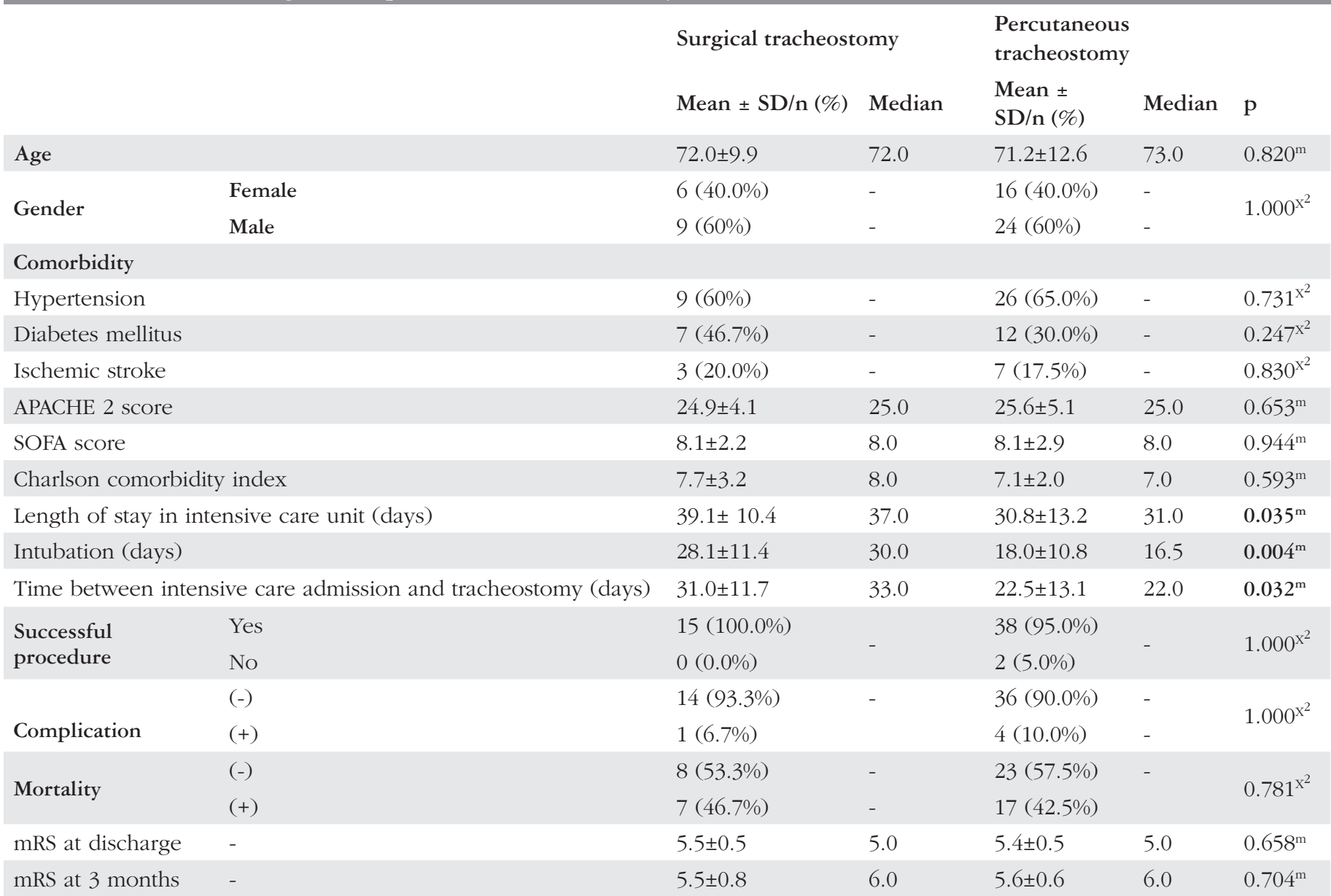

m: Mann-Whitney U test, $\mathrm{X}^{2}$ : Chi-square test (Fischer test), SD: Standard deviation, APACHE 2: Acute Physiology and Chronic Health Evluation 2 score, SOFA: Sequential Organ Failure Assessment score, mRS: Modified Rankin scale

the complication rates of the two groups. There were $8(53.3 \%)$ patients with a discharge mRS score of 5 in the surgical group, and $24(60.0 \%)$ in the percutaneous tracheostomy group. While there were $7(46.7 \%)$ patients with an mRS score of 6 discharging from the ICU in the surgical group, there were $16(40.0 \%)$ patients in the percutaneous tracheostomy group. There was no statistically significant difference $(\mathrm{p}=0.658)$.

When different subgroups such as LMA, endotracheal tube withdrawal, and bronchoscopy were compared in patients undergoing percutaneous tracheostomy, no statistically significant difference was observed in mortality, discharge, $3^{\text {rd }}$ month mRS score, successful procedure and/or complication rates, as well as other analyzed parameters ( $\mathrm{p}>0.05)$ (Table 3). During percutaneous tracheostomy, LMA was used in $17(42.5 \%)$ patients, endotracheal tube withdrawal was used in $12(30.0 \%)$ patients, and bronchoscopy was used in $11(27.5 \%)$ patients. The complication rate was $11.8 \%$ in the LMA group and $16.7 \%$ in the tube withdrawal group. No complications were observed in the bronchoscopy group. There were 2 patients in the percutaneous tracheostomy group who underwent tracheostomy with the endotracheal tube withdrawal method, which resulted in failure and death due to false passage. Esophageal rupture was observed in one of these patients, and widespread emphysema with rapid progression in the subcutaneous tissues was observed in the other patient.

\section{Discussion}

Cerebrovascular diseases (ischemic stroke, intracranial hemorrhage and subarachnoid hemorrhage) constitute the majority of the patient population followed up in the neurological ICU. In this group of patients with extensive brain damage, mechanical ventilation may be needed from the early period of hospitalization. As the number of days intubated increases, the ventilator-associated pneumonia and in-hospital mortality rates increase, or the intensive care follow-up period is prolonged. For this reason, it is important to evaluate patients with stroke who may undergo prolonged intubation in terms of tracheostomy in the early period. Tracheostomy is also performed in diseases such as GBS, amyotrophic lateral sclerosis, myasthenia gravis and myopathy, which are rarely seen in neurological ICU. GBS, as we know, is an acute onset and rapidly progressing disease which may require intensive care follow-up with intubation as a result of affected respiratory muscles. Since the rehabilitation process of these patients continues for months, if the need for long-term mechanical ventilation continues, tracheostomy may 
Table 3. Evaluation of laryngeal mask, tube withdrawal and bronchoscopy results used during percutaneous tracheostomy procedure

\begin{tabular}{|c|c|c|c|c|c|}
\hline & & $\begin{array}{l}\text { Laryngeal mask } \\
\text { Mean } \pm \text { SD n }(\%)\end{array}$ & $\begin{array}{l}\text { Tube withdrawal } \\
\text { Mean } \pm \text { SD n }(\%)\end{array}$ & $\begin{array}{l}\text { Bronchoscopy } \\
\text { Mean } \pm \text { SD n }(\%)\end{array}$ & $\mathrm{p}$ \\
\hline \multirow{2}{*}{ Age } & Mean \pm SD & $70.0 \pm 14.4$ & $73.7 \pm 12.2$ & $69.2 \pm 10.3$ & \multirow{2}{*}{$0.691^{\mathrm{K}}$} \\
\hline & Median & 73.0 & 72.5 & 73.0 & \\
\hline \multirow{2}{*}{ Gender } & Female n (\%) & $6(35.3 \%)$ & $6(50.0 \%)$ & $4(36.4 \%)$ & \multirow{2}{*}{$0.699^{x^{2}}$} \\
\hline & Male n (\%) & $11(64.7 \%)$ & $6(50.0 \%)$ & $7(63.6 \%)$ & \\
\hline \multirow{2}{*}{ APACHE 2} & Mean \pm SD & $25.7 \pm 5.9$ & $27.1 \pm 4.8$ & $23.8 \pm 3.7$ & \multirow{2}{*}{$0.317^{\mathrm{K}}$} \\
\hline & Median & 25.0 & 27.0 & 24.0 & \\
\hline \multirow{2}{*}{ SOFA } & Mean \pm SD & $8.8 \pm 3.2$ & $9.0 \pm 2.2$ & $5.9 \pm 2.0$ & \multirow{2}{*}{$0.011^{\mathrm{K}}$} \\
\hline & Median & 9.0 & 9.0 & 5.0 & \\
\hline \multirow{2}{*}{ Charlson comorbidity index } & Mean \pm SD & $7.5 \pm 2.4$ & $6.8 \pm 1.8$ & $6.6 \pm 1.6$ & \multirow{2}{*}{$0.494^{\mathrm{K}}$} \\
\hline & Median & 7.0 & 7.0 & 6.0 & \\
\hline \multirow{2}{*}{$\begin{array}{l}\text { Length of stay in intensive care } \\
\text { unit (days) }\end{array}$} & Mean \pm SD & $26.2 \pm 10.9$ & $42.1 \pm 12.1$ & $25.7 \pm 10.6$ & \multirow{2}{*}{$0.001^{\mathrm{A}}$} \\
\hline & Median & 28.0 & 40.0 & 31.0 & \\
\hline \multirow{2}{*}{ Number of days intubated } & Mean \pm SD & $14.5 \pm 11.1$ & $23.8 \pm 10.1$ & $17.0 \pm 9.1$ & \multirow{2}{*}{$0.062^{\mathrm{K}}$} \\
\hline & Median & 8.0 & 26.5 & 14.0 & \\
\hline \multirow{2}{*}{ Successful procedure } & Yes n (\%) & 17 (100.0\%) & $10(83.3 \%)$ & 11 (100.0\%) & \multirow{2}{*}{$\mathrm{p}>0.05^{\mathrm{x}^{2}}$} \\
\hline & No n (\%) & $0(0.0 \%)$ & $2(16.7 \%)$ & $0(0.0 \%)$ & \\
\hline \multirow{2}{*}{ Complication } & $(-)$ n $(\%)$ & $15(88.2 \%)$ & $10(83.3 \%)$ & $11(100.0 \%)$ & \multirow{2}{*}{$\mathrm{p}>0.05^{\mathrm{x}^{2}}$} \\
\hline & $(+) \mathrm{n}(\%)$ & $2(11.8 \%)$ & $2(16.7 \%)$ & $0(0.0 \%)$ & \\
\hline \multirow{2}{*}{ Mortality } & $(-)$ n (\%) & $11(64.7 \%)$ & $5(41.7 \%)$ & $7(63.6 \%)$ & \multirow{2}{*}{$0.414^{\mathrm{x}^{2}}$} \\
\hline & $(+) \mathrm{n}(\%)$ & $6(35.3 \%)$ & $7(58.3 \%)$ & $4(36.4 \%)$ & \\
\hline \multirow{2}{*}{$\mathrm{mRS}$ at discharge } & Mean \pm SD & $5.4 \pm 0.5$ & $5.6 \pm 0.5$ & $5.3 \pm 0.5$ & \multirow{2}{*}{$0.284^{\mathrm{K}}$} \\
\hline & Median & 5.0 & 6.0 & 5.0 & \\
\hline \multirow{2}{*}{ mRS at 3 months } & Mean \pm SD & $5.7 \pm 0.6$ & $5.6 \pm 0.7$ & $5.5 \pm 0.5$ & \multirow{2}{*}{$0.349^{\mathrm{K}}$} \\
\hline & Median & 6.0 & 6.0 & 5.0 & \\
\hline
\end{tabular}

become the only option that will ensure the discharge of patients from neurological ICU. Patients with advanced amyotrophic lateral sclerosis and myopathy, in whom respiratory muscles are insufficient to maintain respiration and upper respiratory tract patency cannot be maintained due to insufficiency of nasopharyngeal and laryngeal muscles, are also intubated in neuroICUs. Early tracheostomy procedures are important for these patients to be discharged from ICU to palliative care services or home $(1,6,7)$. In our study, $80 \%$ of the patients who underwent tracheostomy had cerebrovascular diseases. The remainder had amyotrophic lateral sclerosis, myasthenia gravis, myopathy, and GBS. Two patients without a primary neurological diagnosis were hospitalized in our ICU with the diagnosis of COVID-19 during the pandemic. In our study, there were $23(41.8 \%)$ patients whose hospital follow-up period ended in death and had an mRS score of 6 at discharge. All of these patients were patients with stroke. In the current literature, the mortality rate in the cerebrovascular diseases group has been reported to be higher compared to the other groups (8).
In the literature, there are many studies comparing surgical and percutaneous tracheostomy results $(8,9,10,11,12,13)$. Among these studies, the retrospective study conducted by Yaka et al. (13) on patients with stroke in neuro-ICU draws attention. In this study, when bedside percutaneous tracheostomy procedures performed by neurologists were compared with surgical tracheostomy, no significant difference was found in terms of complication and death rates (13).

Today, although the application of surgical tracheostomy in intensive care patients has decreased significantly, there are still centers that apply it. In our center, surgical tracheostomy is applied to patients in whom we predict difficulties in the percutaneous tracheostomy procedure (anatomical short neck, spinal cord deformities such as scoliosis, obesity, thyroid hyperplasia, previous neck surgery). Surgical tracheostomy was performed in $27.3 \%$ of the patients included in the study. Bedside percutaneous tracheostomy was performed in $72.7 \%$ of the patients. General anesthesia was applied to all patients in the surgery group, while neurosedation was applied to the percutaneous tracheostomy 
group by neurology ICU specialists. Many studies have shown that complication rates are lower in percutaneous tracheostomy compared to surgical tracheostomy $(8,10,12)$.

On the other hand, although percutaneous tracheostomy is a method that can be applied easily in a short time, it has been reported that peroperative complications and mortality rates increase, especially when performed by inexperienced practitioners (9). Complication rates of percutaneous tracheostomy have been reported in the literature between $1 \%$ and $10 \%(8,14)$. In our study, this rate was $10 \%$ in patients undergoing percutaneous tracheostomy. While reviewing the causes of complications in our study group, complications such as bleeding from the stoma after the procedure were observed in 3 patients. Surgical technique was applied in one of these patients, and percutaneous tracheostomy was performed in the other two patients. In the retrospective review, it was seen that these patients had to use antiaggregant due to aneurysm treatment/flow diverting stent or emergency stenting during mechanical thrombectomy. Two patients died as a result of incorrect passage. Percutaneous tracheostomy was performed with tube withdrawal method in these 2 patients. While the procedure failure rate was $5 \%$ in percutaneous tracheostomy, no unsuccessful procedure was found in patients who underwent surgical procedure. Tracheostomy time was longer in the surgical tracheostomy group than in the percutaneous tracheostomy group, according to the length of stay in the ICU, the number of days followed up with intubating and the day of hospitalization in the ICU. The reason for this is due to the prolongation of the preoperative evaluation process before the surgical tracheostomy procedure and delay in determining of the operation day. Prolonging the length of stay in the ICU brings with it the risk of nosocomial infection and increased in-hospital care costs.

During the percutaneous tracheostomy procedure, there are different methods applied by withdrawing the bronchoscope, LMA or intubation tube $(15,16,17,18)$. Considering the tracheal structures in a study, it was shown that the use of LMA was advantageous over the endotracheal tube withdrawal method (15). Strametz et al. (16), on the other hand, claimed that the use of LMA did not provide safe airway patency in critically intensive care patients. In another study comparing the use of LMA and the results of tracheostomy performed by withdrawing the intubation tube, it was emphasized that there were insufficient data to make a definitive decision about efficacy or safety, that there might be late complications especially in the use of LMA, and that there was not enough research on this subject (17). In addition, there are studies in the current literature showing that the results of percutaneous tracheostomy performed with bronchoscopy are good and the complication rates are low $(18,19,20,21)$.

In our study, while procedural failure was not observed in the patients in whom LMA and bronchoscopy were used, serious complications such as subcutaneous emphysema and esophageal rupture were observed as a result of incorrect passage in two patients who underwent tracheostomy with tube withdrawal. As a result, the patients died in the early period. A retrospective analysis of our own database showed that percutaneous tracheostomy would not be appropriate for patients with an indication for surgical tracheostomy, without assistive techniques such as bronchoscopy. In the current literature, there are also studies showing that the results of percutaneous tracheostomy performed by experienced personnel, accompanied by bronchoscopy, are successful in many patients with surgical tracheostomy indications (short neck, obesity, thyroid hyperplasia, soft tissue infection in the neck, inability to extend the neck, presence of pulsatile veins in the procedure area, coagulation disorders, malignancy in the procedure area, history of neck surgery, history of tracheostomy) $(19,22,23)$. There are also studies showing that the results of percutaneous tracheostomy performed with bronchoscopy by experienced personnel are successful $(19,22,23)$.

\section{Study Limitations}

The most important limitation of the study was the small number of patients in our cohort, as well as the low number of neurological diseases other than stroke. Since it was a retrospective study, it was not possible to evaluate parameters such as the duration of the tracheostomy procedure.

\section{Conclusion}

In the study in which we compared surgical and percutaneous tracheostomy results, no significant difference was found between the complication rates of the two groups. Although the mRS score at discharge did not differ statistically significantly, the mortality rate, indicated by the mRS score of 6 , was higher in the surgical group.

As a result of the rapid application of the procedure at the bedside in patients for whom percutaneous tracheostomy is preferred, the length of stay in the tertiary neurological ICU and the number of days followed up with intubation can be reduced. Therefore, the risk of in-hospital infection and the cost of intensive care can be reduced. Performing percutaneous tracheostomy with bronchoscopy reduces the possibility of complications even in the most difficult patients.

Ethics

Ethics Committee Approval: The study was approved by the Eskisehir Osmangazi University Faculty of Medicine Ethics Committee (decision number: E-25403353-050.99-183151).

Informed Consent: This study did not require informed consent.

Peer-review: Internally peer-reviewed.

\section{Authorship Contributions}

Surgical and Medical Practices: F.M., F.G.A., Z.M., Ö.A., M.Ö.P., M.K.G., A.Ö.Ö., Concept: A.Ö.Ö., Design: A.Ö.Ö., Data Collection or Processing: F.M., F.G.A., Z.M., Ö.A., Analysis or Interpretation: F.M., A.Ö.Ö., Ö.A., Literature Search: F.M., Writing: F.M.

Conflict of Interest: No conflict of interest was declared by the authors.

Financial Disclosure: The authors declared that this study received no financial support.

\section{References}

1. Bösel J, Schiller P, Hook Y, et al. Stroke-related early tracheostomy versus prolonged orotracheal intubation in neurocritical care trial (SETPOINT): a randomized pilot trial. Stroke 2013;44:21-28.

2. Trouillet JL, Collange O, Belafa F, et al. Tracheotomy in the intensive care unit: guidelines from a French expert panel. Ann Intensive Care 2018;8:37.

3. MacIntyre NR, Cook DJ, Ely EW, et al. Evidence-based guidelines for weaning and discontinuing ventilatory support: a collective task force facilitated by the American College of Chest Physicians; the American 
Association for Respiratory Care; and the American College of Critical Care Medicine. Chest 2001;120(Suppl 6):375S-395S.

4. MacIntyre N. Discontinuing mechanical ventilatory support. Chest 2007;132:1049-1056.

5. Susaman N, Hanbeyoglu O. Comparison between surgical and percutaneous tracheostomy effects on geriatric patients in the ICU. Turkish Journal of Geriatrics 2020;23:188-196.

6. Bösel J. Tracheostomy in stroke patients. Curr Treat Options Neurol 2014;16:274.

7. Schönenberger S, Al-Suwaidan F, Kieser M, Uhlmann L, Bösel J. The SETscore to predict tracheostomy need in cerebrovascular neurocritical care patients. Neurocrit Care 2016;25:94-104.

8. Kırca H, Çakın Ö, Cengiz M, Yılmaz M, Ramazanoğlu A. Tracheotomy in the intensive care unit: Indications, complications and prognosis. J Turk Soc Intensive Care 2018;16:17-25.

9. Sağıroğlu AE, Ağkoç E, Doğan Y, et al. Yoğun bakım ünitesinde perkütan ve cerrahi trakeostominin karşılaştırılması. Göztepe Tip Dergisi 2010;25: 67-70.

10. Putensen C, Theuerkauf N, Guenther U, Vargas M, Pelosi P. Percutaneous and surgical tracheostomy in critically ill adult patients: a meta-analysis. Crit Care 2014;18:544

11. Veenith T, Ganeshamoorthy S, Standley T, Carter J, Young P. Intensive care unit tracheostomy: a snapshot of UK practice. Int Arch Med 2008;1:21.

12. Delaney A, Bagshaw SM, Nalos M. Percutaneous dilatational tracheostomy versus surgical tracheostomy in critically ill patients: a systematic review and meta-analysis. Crit Care 2006;10:R55.

13. Yaka E, Mengi T, Keskinoglu P. Tracheostomy in patients with ischemic stroke. Turkish Journal of Cerebrovascular Diseases 2019; 25:145-149.

14. Servillo G, Pelosi P. Percutaneous tracheostomy in critically Ill patients. 1st ed. Switzerland: Springer International Publishing, 2016.
15. Linstedt U, Zenz M, Krull K, Häger D, Prengel AW. Laryngeal mask airway or endotracheal tube for percutaneous dilatational tracheostomy. Anesth Analg 2010;110:1076-1082.

16. Strametz R, Pachler C, Kramer JF, et al. Laryngeal mask airway versus endotracheal tube for percutaneous dilatational tracheostomy in critically ill adult patients. Cochrane Database Syst Rev 2014;6:CD009901

17. Ambesh SP, Sinha PK, Tripathi M, Matreja P. Laryngeal mask airway vs endotracheal tube to facilitate bedside percutaneous tracheostomy in critically ill patients: a prospective comparative study. J Postgrad Med 2002;48:11-15.

18. Saritas A, Saritas PU, Kurnaz MM, Beyaz SG, Ergonenc T. The role of fiberoptic bronchoscopy monitoring during percutaneous dilatational tracheostomy and its routine use into tracheotomy practice. J Pak Med Assoc 2016;66:83-89.

19. Timuroğlu A, Güngör A, Menteş S, Tunçel Yİ, Ünver S. Our percutaneous tracheostomy experiences performed with the aid of Bronchoscopy. GKDA Derg 2018;24:124-129.

20. Heyrosa MG, Melniczek DM, Rovito P, Nicholas GG. Percutaneous tracheostomy: a safe procedure in the morbidly obese. J Am Coll Surg 2006;202:618-622.

21. Kluge S, Meyer A, Kühnelt P, Baumann HJ, Kreymann G. Percutaneous tracheostomy is safe in patients with severe thrombocytopenia. Chest 2004; 126:547-551.

22. Meyer M, Critchlow J, Mansharamani N, et al. Repeat bedside percutaneous dilational tracheostomy is a safe procedure. Crit Care Med 2002;30:986988.

23. Jackson LS, Davis JW, Kaups KL, et al. Percutaneous tracheostomy: to bronch or not to bronch-- that is the question. J Trauma 2011;71:15531556. 